\title{
INSTITUT ROYAL DU PATRIMOINE ARTISTIQUE RADIOCARBON DATES I
}

ANNE N. SCHREURS, lic. sc. phys.

Institut Royal du Patrimoine Artistique, Brussels, Belgium

\section{INTRODUCTION}

The development of a $\mathrm{C}^{14}$ laboratory within the physical laboratory of the "Institut royal du Patrimoine artistique" was begun by Dr. I. Elskens* and D. Gausset** (A.I.Br.).

The electronic apparatus was clelivered in 1963 and routine counting on gas of petrochemical origin began in 1964. By December 1965 , methane gas was prepared from pure commercial $\mathrm{CO}_{2}$ and, in February 1966, the first test samples were burnt.

We follow the method used in Louvain (Dossin J. M. and Deumer J. M., 1961). Samples are first examined under a binocular to pick up as many rootlets as possible and to remove foreign matters. They are then treated with $1 \% \mathrm{NaOH}$ and $1 \% \mathrm{HCl}$. After being rinsed with distilled water and clried, they are burnt in a stream of oxygen. The released $\mathrm{CO}_{2}$ is purified by passage through the following chemicals and traps: plarinized asbestos, hot $\mathrm{CuO}, 0.1 \mathrm{~N} \mathrm{AgNO}_{3}$ (twice), $\mathrm{H}_{2} \mathrm{SO}_{4}-\mathrm{CrO}_{3}$ solution (twice), acetone dry-ice trap and a serial of 3 liquid air traps.

The $\mathrm{CO}_{2}$ is first purified by pumping off gaseous impurities between displacement from one trap to another and final purification is realized on reduced B.T.S. (finely devised copper adsorbed on a mixture of silica and magnesium oxide, a B.A.S.F. product). The volume of $\mathrm{CO}_{2}$ is measured and mixed in a $26 \mathrm{l}$. glass flask with 4 volumes of $\mathrm{H}_{2}$. Hydrogrenation takes place overnight on a nickel catalyst ( $\mathrm{Ni}$ fixed on pumice: see I.ouvain I) with a yield of $90 \%$ at least. $\mathrm{CH}_{4}$ is purified by trapping water, eliminating $\mathrm{H}_{2}$ on B.T.S. (in the $\mathrm{CuO}$ form), and adsorbing $\mathrm{CO}_{2}$ on molecular sieves. Purity reached during the first preparations was checked by gas chromatography. Samples are then stored in 61 . glass flask for at least 15 clays before counting.

All measurements are made in a stainless steel counter built by the

B.L.E. (Manufacture Belge de Lampes et d'Electronique) after design of Houtermans and Oeschger (1958). Only the preamplifiers are transistorized. The threshold at both proportional counters is $0.5 \mathrm{mV}$; no upper threshold is used.

The composite shield from the same firm consists of: uncler the counter, $10 \mathrm{~cm}$ of steel; on the sides, $5 \mathrm{~cm}$ of steel and $5 \mathrm{~cm}$ of "old" lead; on the top $5 \mathrm{~cm}$ of steel, $8 \mathrm{~cm}$ of paraffin, $1 \mathrm{~cm}$ of steel, $7.5 \mathrm{~cm}$ of "old" lead, $4 \mathrm{~cm}$ of paraffin, $1.5 \mathrm{~cm}$ of boric acid and $8 \mathrm{~cm}$ of paraffin.

Depending upon the size of the sample, the counter is filled at a pressure of 700 to $1500 \mathrm{~mm}$ of $\mathrm{Hg}$. Atmospheric pressure and temperature

\footnotetext{
* Present address: Université de Bruxelles, 50, avenue F.D. Roosevelt, Bruxelles 5. **Now at the Union Chimique Belge, Bruxelles.
} 
are measured at each filling. Plateau-curves are taken with and without source $\left(\mathrm{CO}^{60}\right)$ to locate proper operating voltage.

Serials of about 10 samples are prepared including at least one "living" reference (N.B.S. oxalic acid) and "dead" carbon (anthracite). Samples are counted during two nights, at one month interval and a third time if the measurements do not agree within two standard deviations.

All ages were calculated using as "living" standard 0.95 of the activity measured on N.B.S. oxalic acid and 5,570 yr for the half-life of $\mathrm{C}^{14}, 1950$ being taken as reference year.

As the installation operates in preset count, standard error of activity is calculated by a formula derived by Mme. E. Defrise-Gussenhoven of the "Institut Royal des Sciences Naturelles":

Standard error of the mean

$$
\begin{aligned}
S_{y} & =\frac{1}{\sqrt{n}} \frac{N \cdot S_{t}}{\bar{t}^{2}+S_{t}{ }^{2}} \\
S_{t} & =\frac{\Sigma t_{i}{ }^{2}-\bar{t} \Sigma t_{i}}{n-1}
\end{aligned}
$$

when $\mathrm{n}=$ number of measurements

$\mathrm{N}=$ preset number of counts

$$
\begin{aligned}
& \mathrm{t}_{1}, \mathrm{t}_{2}, \ldots, \mathrm{t}_{\mathrm{i}}, \ldots, \mathrm{t}_{\mathrm{n}}=\text { measurements of time (in seconds) } \\
& \overline{\mathrm{t}}=\frac{\overline{\mathrm{s}} \mathrm{t}_{\mathrm{i}}}{\mathrm{n}}
\end{aligned}
$$

Error of the age is calculated from standard errors of the measurements, using the formula of Crèvecoeur, Vander Stricht, and Capron (1959).

For maximum precision and speed, all calculations were made by an I.B.M. 1130 computer.

From February to October 1966 anthracite was burned 8 times and 17 fillings were made at pressures from 730 to $1300 \mathrm{~mm}$ of $\mathrm{Hg}$. Background depends on filling and atmospheric pressure in the following way:

$A_{0}$ background in counts per second

$$
\mathrm{A}_{\mathrm{o}}=10^{-5}\left(8877+0.8525 \mathrm{p}_{\mathrm{c}}-9.4562 \mathrm{pa}\right)
$$

$p_{\mathrm{a}}$ atmospheric pressure in $\mathrm{mm} \mathrm{Hg}$

pc filling pressure normalized to $20^{\circ} \mathrm{C}$ (in $\mathrm{mm} \mathrm{Hg}$ )

Standard error of the distances to prevision is 136.46 .

Five wet combustions were performed on N.B.S. oxalic acid with a warm $\mathrm{H}_{2} \mathrm{SO}_{4}-\mathrm{Cr} \mathrm{O}_{3}$ solution and 13 measurements at pressures from 760 to $1500 \mathrm{~mm} \mathrm{Hg}$ were combined to yield the activity.

$$
\mathrm{A}_{100}=10^{-5}\left(1205.5+20.14 \mathrm{p}_{\mathrm{c}}\right)
$$

No significant dependence on atmospheric pressure was found. Standard error of the distances to prevision is 481.46.

These functions and errors were used to calculate the age from each measurement on unknown sample combined with matching background and "living wood" reference. 
ACKNOWLEDGMENTS

Acknowledgment is made to Prof. E. Tongiorgi of Pisa and his collaborators for instruction in the use of Oeschger's counter. Prof. P. C. Capron and his staff helped us in the rapid preparation of a line similar to the installation operating in the $\mathrm{C}^{14}$ laboratory at Louvain.

Vacuum lines for preparing samples and filling the counter were constructed in pyrex glass by R. Kléber ${ }^{\dagger}$ and J. Heylen from January 1965 to June 1966. Now, J. Heylen operates the line alone and has also ensured continuous operation of the counter during the author's leave.

\section{SAMPLE DESGRIPTIONS}

Unless otherwise stated, samples, mostly of known age, came from the "Service National des Fouilles." Whenever possible, wood and charcoal were identified by J. Vynckier of the Institute. Descriptions and comments were based on information given by the person submitting the sample.

\section{IRPA-1. Hamont}

$2550 \pm 180$

Charcoal in sandy soil from Bronze age burial mound excavated in 1962 at Hamont, prov. Limburg, Belgium $\left(51^{\circ} 16^{\prime} \mathrm{N}\right.$ Lat, $5^{\circ} 30^{\prime} 30^{\prime \prime} \mathrm{E}$ Long). Comment (H. Roosens): sample comes from a seconclary deposit (cremated bones in urn of Harpstedt type) in Mound $\mathrm{n}^{\mathrm{r}} \mathrm{I}$ which belongs to Middle Bronze age. The chronology of Harpstedt urns is ill-defined: they are not anterior to the Hallstatt C/D (not before 650) but are still found in La Tène period (Iron age). Two samples from Mound $\mathrm{n}^{r}$ III on same site have been dated as Lv-191 and Lv-192 (Louvain IV, 1966) (Roosens and Beex, 1961).

\section{IRPA-2. Neerpelt (de Roosen)}

$$
2467 \pm 100
$$

Charcoal (mainly from oak) in sandy soil coll. 1960 at Neerpelt, prov. Limburg, Belgium $\left(51^{\circ} 13^{\prime} \mathrm{N}\right.$ Lat, $5^{\circ} 27^{\prime} \mathrm{E}$ Long). Comment (H.R.): sample from central deposit (cremation rests in urn) of Grave 53 which had an open peripheric ditch and belongs to recent phase of urnfields: Iron age to 3rd century B.c. (Roosens and Beex, 1961.)

\section{IRPA-3. Mol}

$4094 \pm 240$

Rather soft charcoal (mainly from oak) mixed with coarse sand coll. 1962 at Mol, prov. Antwerpen, Belgium ( $51^{\circ} 15^{\prime} \mathrm{N}$ Lat, $5^{\circ} 15^{\prime} \mathrm{E}$ Long). Comment (H.R.): sample found at base of burial mound belonging to Bell Beaker civilization of maritime type which developed at end of Neolithic (1800 to 2000 в.c.) (Beex and Roosens, 1963).

\section{IRPA-5. Oudenburg}

$1863 \pm 100$

Well-preserved wood (Quercus) from Roman well excavated in 1964 at Oudenburg, prov. West-Vlaanderen, Belgium $\left(51^{\circ} 11^{\prime} \mathrm{N}\right.$ Lat, $3^{\circ} 2^{\prime}$ E Long). Comment (J .Mertens): expected date 1st or 2nd century.

$\dagger$ Now at the "Papeteries de Genval." 
IRPA-6. Brugge

Wood (probably oak) coll. 1958 at Brugge, prov. West-Vlaanderen, Belgium ( $51^{\circ} 13^{\prime} \mathrm{N}$ Lat, $3^{\circ} 12^{\prime} \mathrm{E}$ Long). Part of pole used to support St. Donatien church on peaty ground. Comment (J.M.): expected date 9 th to 10 th century. Older date may be due to choice of old tree or contamination by humic acid.

\section{IRPA-7. Neerpelt (Achelse dijk)}

$2710 \pm 150$

Charcoal (mainly from oak) in sandy soil coll. 1964 at Neerpelt, prov. Limburg, Belgium $\left(51^{\circ} 13^{\prime} \mathrm{N}\right.$ Lat, $5^{\circ} 27^{\prime} \mathrm{E}$ Long). Comment (H.R.): sample found with cremated bones in urn belonging to older phase of urnfields (end of Bronze age, 7 th or 8 th century B.c.)

\section{IRPA-8. Beerlegem}

$1686 \pm 180$

Beam (Quercus) found in Merovingian grave under $2 \mathrm{~m}$ of glauconiferous sand in 1958 at Beerlegem, prov. West-Vlaanderen, Belgium $\left(50^{\circ} 54^{\prime} \mathrm{N}\right.$ Lat, $3^{\circ} 45^{\prime} \mathrm{E}$ Long). Sample was part of funeral chamber. Comment (H.R.): expected date (a. A.D. 600; older date may be due to use of old tree. Sample of same grave has been dated as Lv-26 (Louvain $\mathrm{V}, 1967)$.

\section{IRPA-9. Oplinter}

$1336 \pm 240$

IVood (Quercus) chipped from center of triumphal cross treated at thr Institute during 1964 and conserved at Oplinter, prov. Brabant, Belgium (50 $49^{\prime} \mathrm{N}$ Lat, $4^{\circ} 59^{\prime} \mathrm{E}$ Long). Comment: expected date 13 th century. (de Borchgrave d'Altena, 1933). Unprecise result due to smallness of sample and lack of second counting as gas was polluted by air.

\section{IRPA-10. Lillo}

Wood (probably Quercus) excavated in 1965 at Lillo, prov. Antwerpen, Belgium $\left(51^{\circ} 18^{\prime} \mathrm{N}\right.$ Lat, $4^{\circ} 18^{\prime} \mathrm{E}$ Long). Taken at $2-\mathrm{m}$ depth from a pole supporting tower of the church. Comment (J.M.): village was destroyed by water in 1585 and rebuilt in 1651. The same event occurred in 1832. Date shows that pole is probably not from 17 th century construction $(95 \%$ chance).

\section{IRPA-11. Easter Island}

Wet charcoal ( $50 \%$ water) coll. 1955 by F. Mazières at Rano Ravaku on Easter Island, Republic of Ecuador (27 $08^{\prime} \mathrm{S}$ Lat, $109^{\circ} 23^{\prime} \mathrm{W}$ Long); subm. by Institut des Sciences naturelles, Brussels. Found at depth $50 \mathrm{~cm}$ in very porous soil and kept in polyethylene vial. Comment (A. Capart): not $15^{\text {th }}$ century as suggested by nearby statues. Samples from same site were dated as K-507, K-521, and K-508 (Copenhagen V, 1962). 
IRPA-12. Tongres Belgium $\left(50^{\circ} 48^{\prime} \mathrm{N}\right.$ Lat, $5^{\circ} 28^{\prime} \mathrm{E}$ Long) on site of temple.

\section{Urnfield series}

Six samples from excavations in 1960 at Neerpelt (de Roosen), prov. Limburg, Belgium (5 $1^{\circ} 13^{\prime} \mathrm{N}$ Lat, $5^{\circ} 20^{\prime} \mathrm{E}$ Long) and nearby locality of Achel (Pastoorbos) (15 $15^{\circ} \mathrm{N}$ Lat, $5^{\circ} 29^{\prime} \mathrm{E}$ Long). Dates should range from 1000 to 400 B.c. All samples consisted of charcoal mixed with sand, humus, and rootlets. Those from Neerpelt belong to recent phase of urnfields (Iron age). IRPA-1 and 2 also are of this period (Roosens and Bcex, 1961, 1962, and 1967).

\section{IRPA-13. Neerpelt}

$$
2336 \pm 100
$$

From ditch of Grave 44 (open (litch type).

386 B.C.

IRPA-14. Neerpelt

$2646 \pm 230$

From ditch of Grave 49 open ditch type). Comment (H.R.): date seems a little too old.

IRPA-15. Neerpelt

$2434 \pm 125$

484 B.C.

From central deposit of Grave 57 (cremation rests in Harpstedt urn).

IRPA-16. Neerpelt

$2657 \pm 190$

From ditch of Grave 71 (open ditch type). At center were found some sherds of Harpstedt urn. Comment (H.R.): date seems a little too old.

\section{IRPA-17. Neerpelt}

$2775 \pm 130$

Only sample of coniferous wood charcoal, from Grave 124 surrounded not only by ditch but also by an earth bank. Barrow type ditch is seldom seen in urnfields but is mostly found in Early and Middle Bronze age. Comment (H.R.): no remains of funerary deposit were found; sample was coll. under mound in rubbish pit which yielded also some pieces of flint. Thus, it is probably anterior to general chronology of urnfield.

\section{IRPA-18. Achel}

$2761 \pm 340$

Charcoal coll. 1964 in funerary Deposit 58 with cremated bones and sherds of urn. Comment (H.R.): belongs to older phase of urnfields (Final Bronze age).

IRPA-19. Ordona

$$
1959 \pm 180
$$

9 B.C.

Well-preserved charcoal excavated at end of 1965 at Ordona, prov. Foggia, Italy $\left(41^{\circ} 18^{\prime} \mathrm{N}\right.$ Lat, $15^{\circ} 37^{\prime} \mathrm{E}$ Long). Found at 3-m depth much 
above ground-water level in fills of cryptoportic on forum. Comment (J.M.): most probably lst century A.D. (Trajan).

\section{IRPA-20. Chèvremont}

$$
1103 \pm 125
$$

Charcoal found at 2.10-m depth in orchard during excavations in 1966. Belongs to burned horizon on site of feudal castle. Two independent experiments were made:

Fraction A normally pretreated: $1086 \pm 180$

$$
\text { A.D. } 864
$$

Fraction B acidic wash only: $1120 \pm 180$

$$
\text { A.D. } 830
$$

Comment: sample from same site at 1.15-m depth dated as LV-228 (Louvain IV, 1966). Agreement of both measurements shows absence of important contamination by humic acids although earth seemed very rich in organic matter; many rootlets had to be handpicked. Age given is mean of two determinations.

\section{IRPA-21. Tongres}

$$
2150 \pm 190
$$

Clay containing charcoal from burned beam in Roman layer at depth $3.02 \mathrm{~m}$ excavated in May 1966 at Tongres, prov. Limburg, Belgium $\left(50^{\circ} 48^{\prime} \mathrm{N}\right.$ Lat, $51^{\circ} 28^{\prime} \mathrm{E}$ Long). Comment: expected date lst or 2nd century A.D.

\section{IRPA-23. Zele}

$$
\begin{array}{r}
1259 \pm 180 \\
\text { A.D. } 691
\end{array}
$$

Wood (Quercus) from head of Viking boat treated at the Institute in 1956. Subm. by J. Douillez, Antwerpen, Oudheidkundige Musea, probably found at Zele, prov. Oost-Vlaanderen, Belgium $\left(51^{\circ} 03^{\prime} \mathrm{N}\right.$ Lat, $4^{\circ} 02^{\prime}$ E Long) during dredging of Schelde. Comment: before usual washes, resinous coating was removed by refluxing in chloroform. Two incursions of Vikings in direction of Ghent took place in 850 and 879 (De Laet, 1956).

\section{IRPA-24. Zillis}

$$
892 \pm 165
$$

Resinous wood from painted ceiling in medieval construction at Zillis, cant. Ticino, Switzerland $\left(46^{\circ} 38^{\prime} \mathrm{N}\right.$ Lat, $9^{\circ} 26^{\prime} \mathrm{E}$ Long). Sent to Dr. Coremans in 1952 by H. Boissonnas from Zurich probably as check sample dated 1130.

\section{IRPA-25. Suse}

$5093 \pm 105$

3143 B.C.

Charcoal (Salix or Populus) found cluring excavations in 1965 on Acropolis of Suse, prov. Khuzistan, Iran (31 $11^{\prime} \mathrm{N}$ Lat, $48^{\circ} 17^{\prime} \mathrm{E}$ Long); subm. by H. Gasche. From fire in archaeological layer at $35 \mathrm{~cm}$ depth on floor of room. A firestone and wall of unbaked bricks stood nearby. Comment: most probably 2700 в.c. (limits, 2300 to 2850 в.C.). 


\title{
IRPA-26. Suse
}

$3136 \pm 150$

Charcoal (Salix or Populus) from oven found in archaeological layer at $75 \mathrm{~cm}$ depth on same site as Sample IRPA-25. Comment: most probably 2750 B.c. (limits, 2300 to 2850 B.c.).

\section{IRPA-27. Suse (Bard-e-Nechandeh)}

$1196 \pm 316$

Wood (Cedrus) found in 1965 on site of Royal Town, now a cornfield. Coll. at $50=\mathrm{cm}$ depth on floor of room. Comment: most probable age 1 st or 2 nd century B.c.

\section{IRPA-28. Feluy}

Carbonized coniferous wood from Château Scaron at Feluy, prov. Hainaut, Belgium $\left(50^{\circ} 33^{\prime} \mathrm{N}\right.$ Lat, $4^{\circ} 17^{\prime} \mathrm{E}$ Long).

Experiment $A: 121 \pm 300$

Experiment B: $87 \pm 94$

Comment: as this part of castle was built in 1830 and burned in 1964, sample was tried as secondary recent stantiard.

\section{Date lists:}

\section{REFFRENCFS}

\author{
Copenhagen V H. Tauber, 1962 \\ Louvain I J. M. Dossin, J. C. Deumer, P. C. Capron, 1962 \\ Louvain IV $\quad$ E. Gilot, N. Ancion, P. C. Capron, 1966 \\ Louvain V E. Gilot, 1967
}

Becx, G. and Roosens, H., 1963, Drieperiodenheuvel met klokbekers te Mol, Archacologica Belgica, v. 72, 23p., ill.

Borchgrave d'Altena, Comte J. de, 1933, La Croix triomphale d'Oplinter: Bull. de la Soc. Roy. d'Archéologie de Bruxelles, no. 2, p. 73-77, 6 figs.

Crevecoeur, E. H., Vander Stricht, A., and Capron, P. C., 1959, Precision of the dating method. Standardization of the calculation of the errors and the maximum age in the C14 method: Acad. Roy. Belgique Bull. cl. sci., v. 45, p. 876-890.

De Laet, S. J., 1956, Wooden animal heads of carolingian times found in the River Scheldt (Belgium) : Acta Archacol., v. 27, Copenhagen, pp. 127-137.

Dossin, J. M. et Deumer, J. M., 1961, Notes sur la détermination des âges par le radiocarbone, Univ. Louvain, 106 p.

Houtermans, F. G. and Oeschger, H., 1958, Proportional zählrohr zur Messung schwacher Aktivitäten weicher B. Strahlung: Acta Phys. Helvetica, v. 31, p. 117-126.

Mertens, J., Ordonna I, 1965 and Ordonna II, 1967, Institut historique Belge de Rome. Roosens, H., 1959, Houten VIIe eeuwse graf kamer met vrouwensieraden te Beerlegem: Archaeologia Belgica, v. 44, 19 p., ill.

Roosens, H. and Beex G., 1961, De opgravingen in het urnenveld "de Roosen" te Neerpelt in 1960: Archaeologia Belgica, v. 58, 56 p., ill.

1962, Het onderzoek van het urnenveld "de Roosen" te Neerpelt in 1961: Archaeologia Belgica, v. 65, 15 p., ill.

1965, Bronstijdgrafheuvels op de Haarterheide te Hamont: Archaeologia Belgica, v. 31,30 p., ill. 38 p., ill. 